\title{
Prototipe Sistem TelemetriBerbasis Sensor Suhu dan Sensor Asap untuk Pemantau Kebakaran Lahan
}

\author{
Boni Pahlanop Lapanporo ${ }^{1}$ \\ 1)Program Studi Fisika, FMIPA, Universitas Tanjungpura, Pontianak, \\ e-mail: boni8poro@gmail.com
}

\begin{abstract}
Abstrak
Telah dilakukan perancangan suatu sistem telemetri berbasis sensor suhu dan sensor asap (smoke detector) untuk pemantau kebakaran lahan. Jenis sensor suhu yang digunakan adalah sensor LM35 dan Sensor asap yang digunakan tipe FG200. Untuk perangkat pengubah data analog keluaran sensor suhu dan sensor asap menjadi sinyal digital digunakan mikrokontroler ATMega8535. Pengiriman data menggunakan modul RF TXM02 pada bagian pemancar (transmitter) dan modul FR RXM01 pada bagian penerima (receiver) yang mampu melakukan transmisi data pada jarak $200 \mathrm{~m}$ di udara terbuka. Tampilan data keluaran hasil pembacaan sensor pada bagian pengirim dan bagian penerima selain dapat ditampilkan pada komputer dengan menggunakan GUI (Graphic User Interface) dengan pemograman Borland Delphi 7.0, juga ditampilkan menggunakan LCD 16 × 2 character. Indikator terjadinya kebakaran (munculnya asap dan suhu lebih dari $37^{\circ} \mathrm{C}$ ) tampak pada menyalanya alarm (buzzer) yang terhubung dengan mikrokontroler. Hasil pengujian menunjukkan bahwa sistem dapat bekerja dengan baik di dalam melakukan pengiriman data informasi suhu dan keberadaan asap di titik pengamatan.
\end{abstract}

\section{Kata Kunci: telemetri, transmisi data, mikrokontroler}

\section{Pendahuluan}

Kebakaran hutan dan lahan merupakan masalah serius yang sering terjadi di wilayah Propinsi Kalimantan Barat. Akibat hal ini tentunya banyak sekali dampak buruk yang ditimbulkan. Dampak yang paling jelas dan nyata adalah kualitas udara menjadi buruk dikarenakan banyaknya asap akibat kebakaran yang tentu saja berdampak buruk bagi kesehatan. Kebakaran hutan dan lahan yang terbesar terjadi pada tahun 1997 yang dampaknya juga dirasakan oleh negara-negara tetangga seperti Malaysia, Singapura dan Filipina.

Sampai saat ini penyebab utama dari kebakaran hutan dan lahan belum terjawab secara rinci, tuntas dan terstruktur. Beberapa pihak berpendapat bahwa kebakaran hutan dan lahan terjadi disebabkan oleh aktivitas pertanian, perkebunan ataupun kehutanan berskala kecil oleh masyarakat lokal dan juga aktivitas perkebunan dan kehutanan berskala besar oleh para pengelola HPH/HTI [5].

Kebakaran hutan yang terjadi secara meluas sebenarnya bisa diatasi dan dicegah bila terdapat suatu sistem peralatan yang dapat mendeteksi secara dini terjadinya kebakaran hutan. Dengan peralatan tersebut, titik terjadinya kebakaran (hotspot) akan segera dapat diketahui sehingga dapat segera dilakukan upaya pemadaman sebelum api menyebar ke wilayah yang lebih luas.

Dalam penelitian ini, dirancang suatu peralatan untuk deteksi dini kebakaran hutan dan lahan yang terdiri dari sistem telemetri berbasis sensor suhu LM35 dan sensor asap (smoke detector). Diharapkan prototipe sistem yang dirancang akan dapat bekerja dengan baik pada cakupan wilayah pengamatan tertentu (skala laboratorium) sehingga bisa dikembangkan dan diaplikasikan di lapangan sebagai alat deteksi dini sistem kebakaran hutan, terutama untuk pemantauan terbentuknya hotspot baru.

\section{Metode}

\subsection{Sistem Telemetri}

Telemetri berasal dari kata "Tele" yang berarti jauh dan "Metri" yang berarti pengukuran. Dengan demikian telemetri adalah suatu sistem komunikasi untuk transfer data pengukuran jarak jauh yang menggunakan media transmisi sebagai carrierdata tersebut. Dengan kata lain dapat dikatakan bahwa telemetri merupakan suatu proses komunikasi secara otomatis yang digunakan untuk mengukur dan mengambil data pada suatu lokasi yang letaknya jauh untuk ditransmisikan ke pusat pengolahan data ${ }^{[3]}$.

Beberapa hal yang perlu diperhatikan dalam telemetri adalah teknik modulasi dan saluran transmisi. Modulasi merupakan proses konversi sinyal informasi menjadi suatu gelombang sinus, atau penumpangan suatu sinyal (sinyal informasi) ke sinyal pembawa (carrier). Ada beberapa macam teknik modulasi 
yang biasa digunakan, tergantung pada parameter yang dimodulasi. Saluran transmisi adalah alat (device) yang dipakai untuk menghubungkan antara sumber data dan penerima data (penampil). Komponen yang dipakai adalah modem (modulator demodulator) dan pemancar penerima radio (radio tranceiver), untuk media transmisi gelombang radio.

Sistem telemetri sering digunakan untuk pengukuran di daerah-daerah yang sukar untuk dijangkau manusia seperti gunung, gua atau lembah. Sistem telemetri juga dapat digunakan untuk monitoring kualitas udara di lingkungan secara real time dengan menempatkan multi sensor asap yang data keluarannya dikirim ke receiver oleh sistem telemetri [2]. Selain untuk pemantauan kondisi lingkungan, sistem telemetri juga diterapkan dalam berbagai bidang. Dalam bidang biologi sistem telemetri digunakan untuk merekam aktivitas neural dari pergerakan ikan di bawah laut[7] dan untuk mengamati aktivitas neural dari hewan-hewan kecil [8].

\subsection{Sensor suhu LM35}

IC LM35 adalah suatu piranti yang dapat memberikan tegangan keluaran (output) yang berubah-ubah secara linier seiring dengan perubahan suhu (temperatur) yang juga terjadi secara linier. Seperti sensor pada umumnya, sensor suhu LM35 bekerja berdasarkan perubahan suhu yang dialami oleh material sensor yang muncul dalam bentuk keluaran berupa tegangan listrik.

LM35 memiliki kelebihan-kelebihan sebagai berikut:dikalibrasi langsung dalam celcius; memiliki faktor skala linear +10.0 mV/ ${ }^{\circ} \mathrm{C}$; memiliki ketepatan $0,5{ }^{\circ} \mathrm{C}$ pada suhu $+25{ }^{\circ} \mathrm{C}$ seperti terlihat pada gambar 2.1; jangkauan maksimal suhu antara $-55{ }^{\circ} \mathrm{C}$ sampai $+150{ }^{\circ} \mathrm{C}$; cocok untuk aplikasi jarak jauh; harga yang cukup murah; bekerja pada tegangan 4 sampai 30 Volt; memiliki arus drainkurang dari $60 \mu \mathrm{A}$; pemanasan sendiri yang lambat (low self heating), $0,08{ }^{\circ} \mathrm{C}$ di udara diam; ketidaklinearan hanya sekitar $\pm 1-4{ }^{\circ} \mathrm{C}$; dan memiliki impedansi keluaran yang kecil, 0,1 W untuk beban $1 \mathrm{~mA}$. Skema dari sensor suhu LM35 ditunjukkan oleh gambar 1.

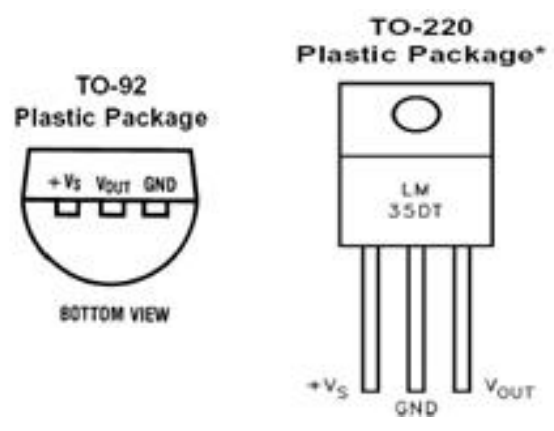

Gambar 1. Sensor suhu LM35

Grafik hubungan akurasi terhadap suhu untuk sensor LM35 ditunjukkan oleh gambar 2.

\section{Accuracy vs. Temperature (Guaranteed)}

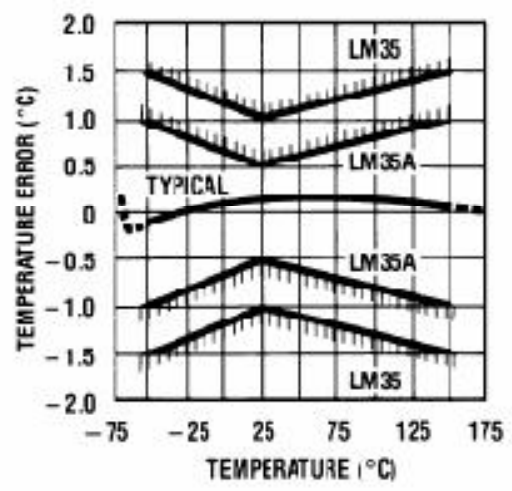

Gambar 2. Grafik Hubungan akurasi terhadap suhu untuk sensor LM35 [6]

LM35 memiliki jangkauan pengukuran suhu maksimum antara $-55^{\circ} \mathrm{C}$ sampai dengan $150^{\circ} \mathrm{C}$ jika dikonfigurasikan seperti gambar 3. Pada perancangan ini LM35 hanya digunakan untuk jangkauan suhu antara $0^{\circ}$ Csampai dengan $150^{\circ} \mathrm{C}$. Keluaran tegangan maksimum LM35 adalah sekitar $1,5 \mathrm{~V}$.

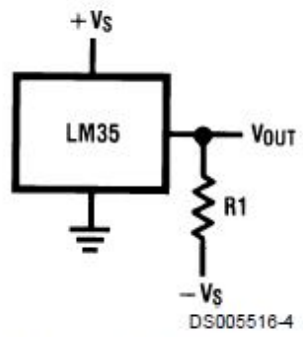

$$
\begin{aligned}
& \text { Choose } R_{1}=-V_{S} / 50 \mu \mathrm{A} \\
& \begin{aligned}
V_{\text {OUT }} & =+1,500 \mathrm{mV} / \text { at }+150^{\circ} \mathrm{C} \\
& =+250 \mathrm{mV} \text { at }+25^{\circ} \mathrm{C} \\
& =-550 \mathrm{mV} \text { at }-55^{\circ} \mathrm{C}
\end{aligned}
\end{aligned}
$$

Gambar 3. Konfigurasi rangkaian LM35[4] 


\subsection{Sensor Asap (Smoke Detector)}

Pada dasarnya prinsip kerja dari sensor asap adalah mendeteksi keberadaan asap hasil pembakaran seperti asap $\mathrm{CO}_{2}$ dan lain sebagainya.Jika sensor tersebut mendeteksi keberadaan asaphasil pembakaran tersebut di udara dengan tingkat konsentrasi tertentu, maka sensor akan mendeteksi bahwa terdapat asap di udara. Ketika sensor mendeteksi keberadaan asap tersebut maka resistansi elektrik sensor akan turun sehingga dapat diketahui kebaradaanasap di udara [1].

\subsection{Garis Besar Sistem Kerja}

Garis besar sistem kerja dari seluruh sistem telemetri data suhu dan detektor asap tertera pada gambar4.Sistem terdiri atas dua bagian, bagian pertama adalah transmitter yang berfungsi untuk mengirimkan data hasil pembacaan sensor suhu dan asap serta memberikan peringatan dini berupa suara melalui buzzer dan display LCD. Bagian kedua adalah bagian receiver yang mampu menerima data suhu dan asap dari transmitter lalu menampilkannya ke display LCD, selain itu receiverjuga mampu memberikan peringatan bahaya dini berupa suara melalui buzzer seperti pada transmitter.

\subsection{Rangkaian Transmitter dan Sensor}

rangkainTransmitter yang dibuat terdiri dari rangkaian sensor, pengkondisi sinyal, modul RF transmitter, sistem minimum mikrokontroler, konverter RS232, penampil LCD dan indikator peringatan. Cara kerja dari sistem transmitter ini mengikuti diagram alir pada gambar 5.

Rangkaian sensor terdiri dari sensor asap dan sensor suhu LM35. Sensor asap memberikan pulsa apabila mendeteksi asap, pulsa tersebut dikondisikan dengan rangkaian pengkondisi sinyal dengan LM555 dan 74HC14 supaya bentuk pulsa menjadi persegi. Sensor suhu akan membaca suhu dengan keluaran tegangan sesuai dengan nilai suhu yang kenaikannya terjadi secara linier. Keluaran sensor suhu dijaga dengan rangkaian dumper untuk menanggulangi perubahan tegangan yang tiba-tiba sehingga pembacaan tegangan sensor di ADC mikrokontroler menjadi stabil.

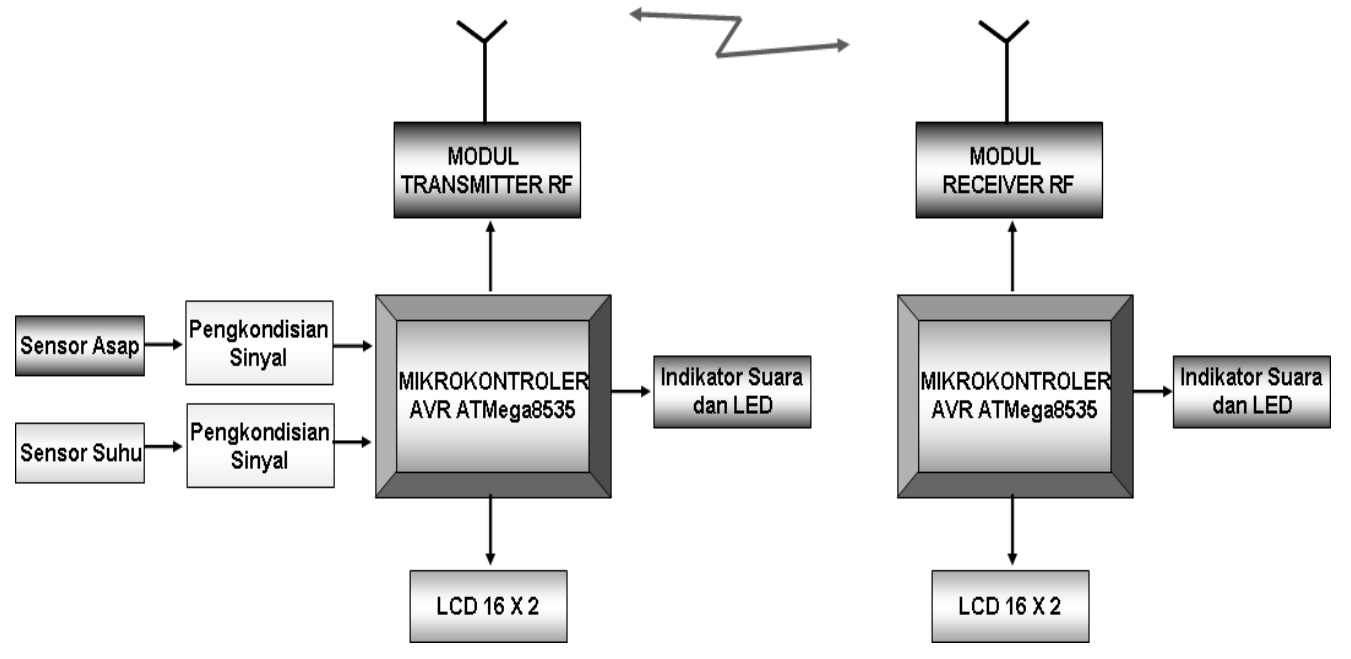

Gambar4. Diagram sistem transmitter dan receiver 


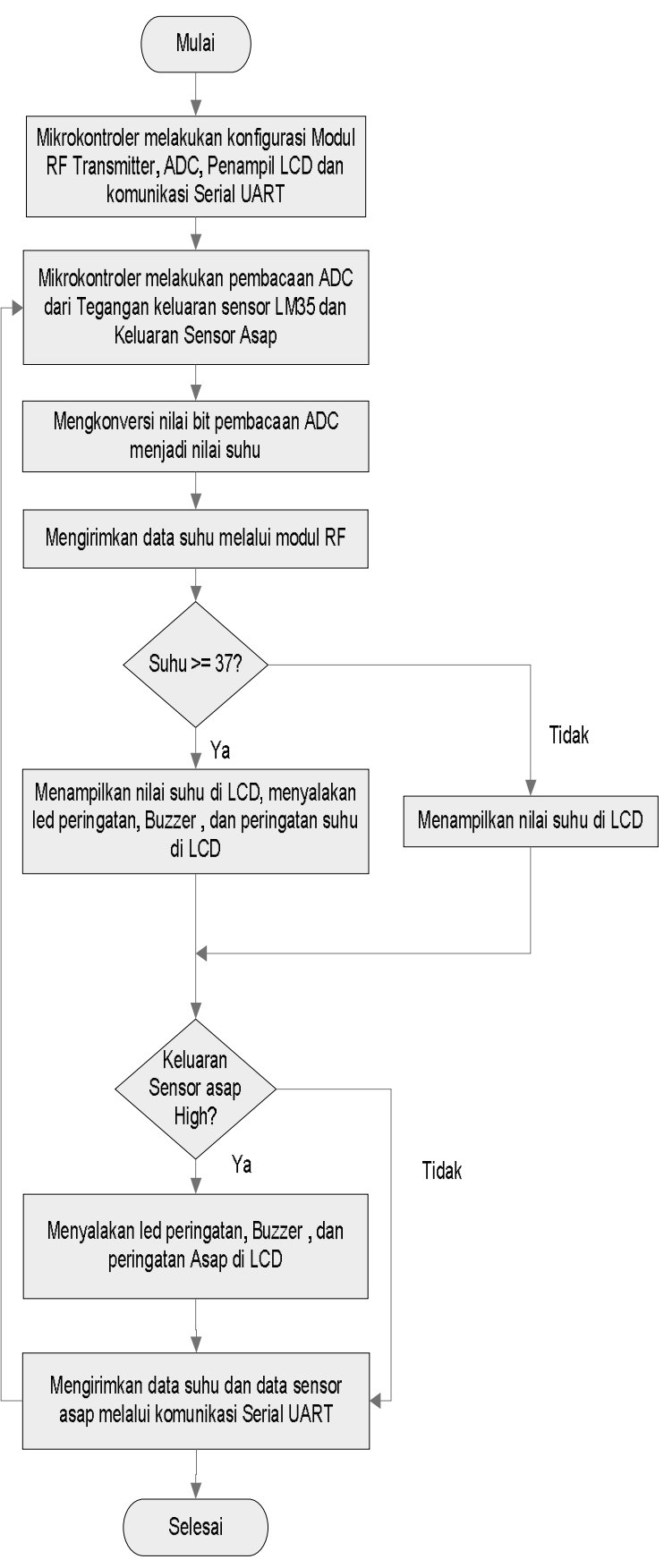

Gambar 5. Diagram alir kerja transmitter

Modul RF transmitter digunakan sebagai pengirim data ke rangkaian receiver. Mikrokontroler membaca data suhu dan asap kemudian mengirimkannya melalui $\mathrm{RF}$ Transmitter. Komunikasi SPI digunakan mikrokontroler untuk mengendalikan $\mathrm{RF}$ Transmitter, setelah data dikirim sistem minimum mikrokontroler menampilkan data tersebut melalui LCD 16x2 karakter. Bila data suhu mencapai $37^{\circ} \mathrm{C}$ dan atau asap terdeteksi maka buzzer akan dihidupkan dan tulisan pada layar LCD akan berkedip. Data hasil bacaan sensor asap dan sensor suhu juga dapat dikirimkan melalui konverter RS232 untuk digunakan sebagai pengolah atau penampil data di komputer yang disebut dengan antarmuka komputer melalui komunikasi serial.

\subsection{Rangkaian Receiver}

Rangkain Receiver yang dibuat terdiri dari modul $\mathrm{RF}$ receiver, sistem minimum mikrokontroler, konverter RS232, penampil LCD dan indikator peringatan. Cara kerja dari sistem receiver ini mengikuti diagram alir pada gambar 6.

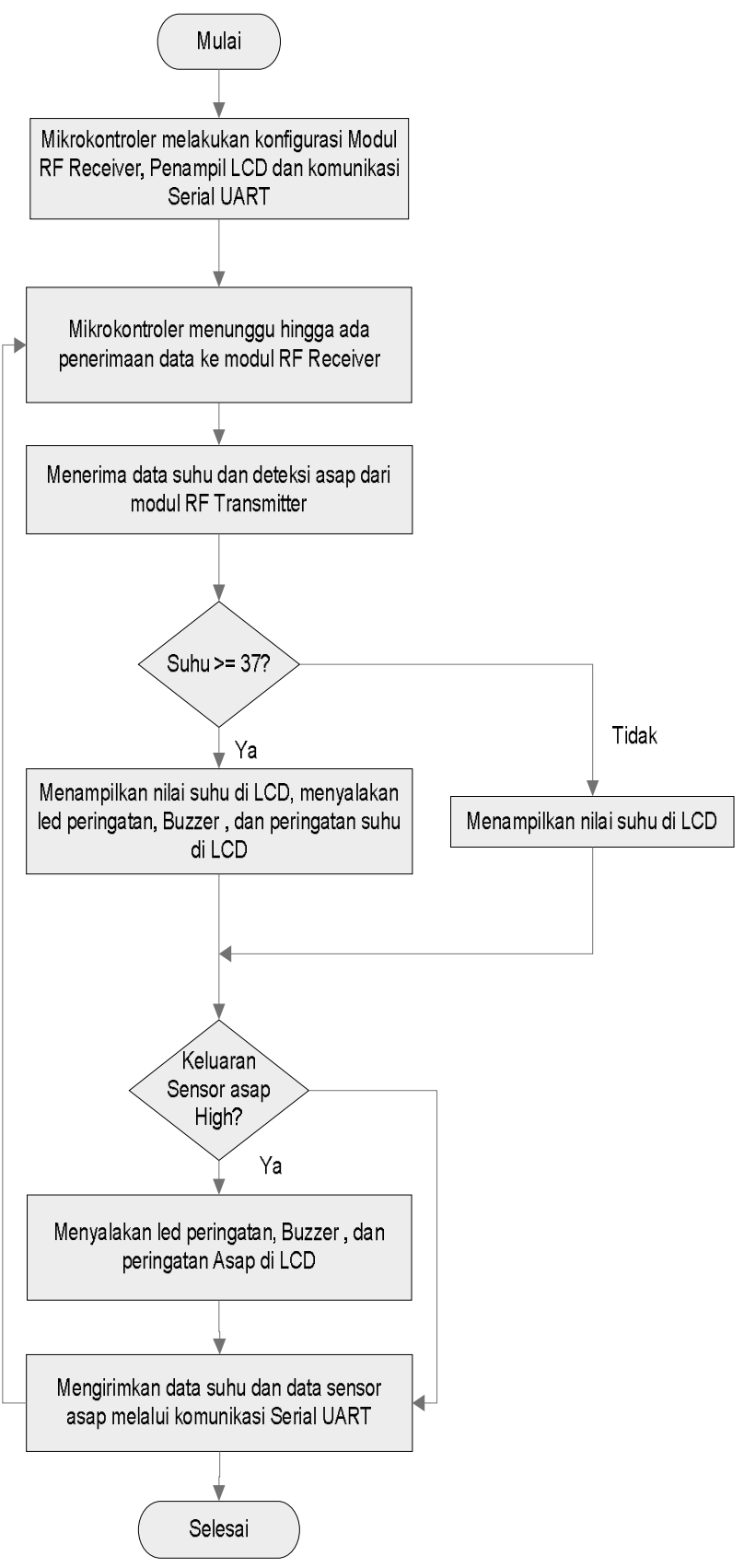

Gambar 6. Diagram alir kerja receiver 
Modul RF receiver digunakan sebagai penerima data suhu dan asap dari rangkaian RF Transmitter yang kemudian dibaca oleh mikrokontroler. Mikrokontroler membaca data suhu dan asap dari modul $\mathrm{RF}$ Receiver. Komunikasi SPI digunakan mikrokontroler untuk membaca data dari RF Receiver, setelah data diterima sistem minimum mikrokontroler akan menampilkan data tersebut melalui LCD $16 \times 2$ karakter.Bila data suhu mencapai $37^{\circ} \mathrm{C}$ dan atau asap terdeteksi maka buzzer akan dihidupkan dan tulisan pada layar LCD akan berkedip. Selain itu, data juga dikirimkan melalui konverter RS232 untuk digunakan sebagai pengolah atau penampil data di komputer yang disebut dengan antarmuka komputer melalui komunikasi serial.

\subsection{Aplikasi Antarmuka Komputer}

Aplikasi antarmuka komputer yang dibuat berfungsi untuk melakukan pembacaan data yang dikirim oleh rangkaian transmitter atau receiver melalui komunikasi serial komputer. Pada aplikasi terdapat dua buah tombol yaitu COM Setting dan Connect.

Tombol COM Setting digunakan untuk mengatur port sambungan dan mode komunikasi serial yang digunakan dan tombol Connect digunakan untuk membuka sambungan data serial dari rangkaian ke computer. Ketika rangkaian transmitter atau receiver mengirimkan data, aplikasi ini akan mencatat waktu pada kolom waktu, data suhu pada kolom suhu dan kondisi asap pada kolom asap, serta data terkini pada dua isian suhu dan asap seperti ditunjukkan pada gambar 7 .

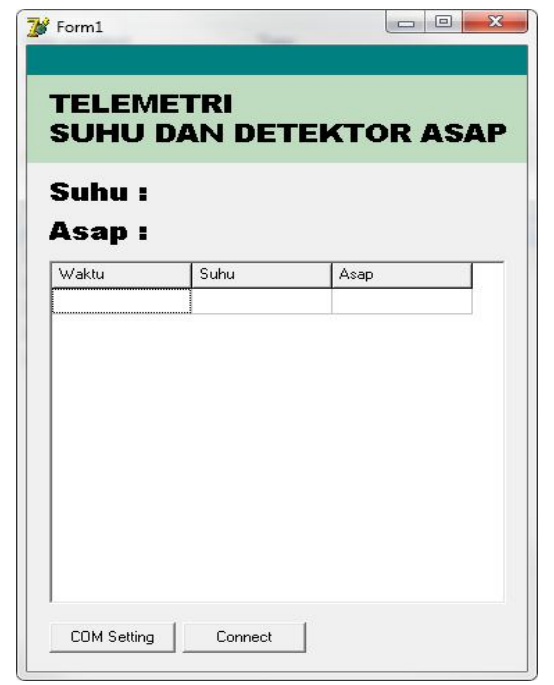

Gambar7. Tampilan aplikasi antarmuka komputer data suhu dan pendeteksi asap

\section{Hasil dan Pembahasan}

\subsection{Hasil Pengujian Pembacaan Data Suhu}

Pengujian pembacaan suhu dilakukan di ruangan, dengan menempatkan bagian transmitter yang dihubungkan dengan sensor suhu dan sensor asap di dalam ruangan. Tampilan data suhu pada display LCD menunjukkan bahwa sensor suhu berhasil mendeteksi perubahan suhu dengan baik yang ditunjukkan dengan berubahnya tampilan data suhu ketika didekatkan dengan sumber panas. Hasil pengujian pembacaan data suhu ditunjukkan oleh gambar 8.

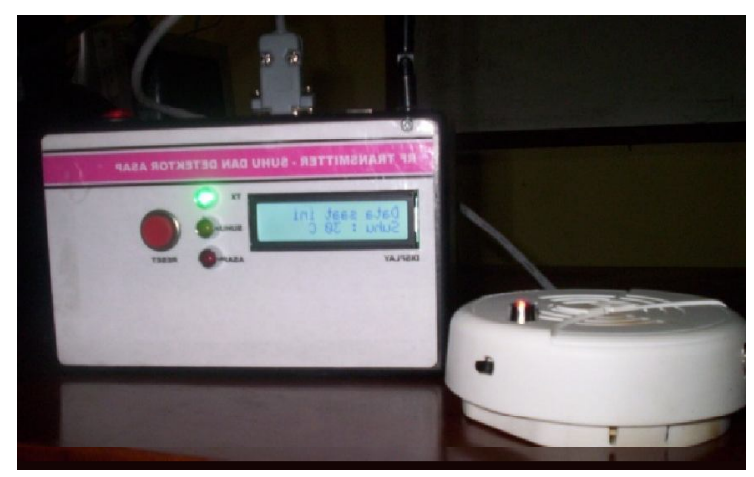

Gambar 8. Hasil pembacaan suhu pada transmitter

Apabila suhu ruangan lebih besar dari $37^{\circ} \mathrm{C}$, maka led kuning dan buzzer peringatan akan menyala.

\subsection{Hasil Pengujian Pembacaan Data Deteksi Asap}

Pengujian pembacaan data deteksi asap dilakukan di ruangan, dengan menempatkan bagian transmitter yang dihubungkan dengan sensor suhu dan sensor asap di dalam ruangan. Tampilan data suhu pada display LCD menunjukkan bahwa sensor asap berhasil mendeteksi keberadaan asap yang terdapat dalam ruangan. Hasil pengujian pembacaan data asap ditunjukkan oleh gambar 9 . 


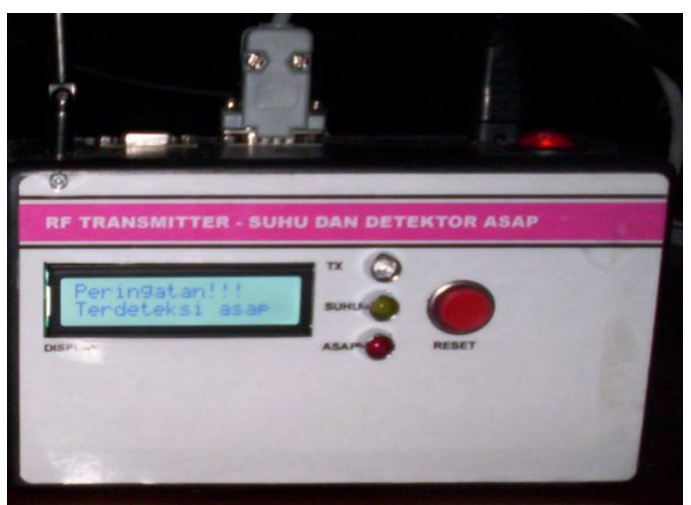

Gambar 9. Hasil pembacaan data asap pada transmitter

Apabila terdapat asap, maka led merah dan buzzer peringatan akan menyala.

\subsection{Hasil Pengujian Pengiriman Data dari}

Transmitter Menuju Receiver

Pengujian dilakukan dengan meletakkan bagian transmitter dan receiver secara sejajar. Hasil pengujian menunjukkan bahwa suhu ruangan yang terdeteksi oleh sensor suhu LM35 yang nilainya ditampilkan pada display LCD bagian transmitter, berhasil dikirimkan ke bagian receiver. Perubahan tampilan data suhu pada display LCD baik pada bagian transmitter maupun pada bagian receiver mengalami perubahan secara serentak. Hal ini menunjukkan bahwa bagian transmitter berhasil melakukan pengiriman data ke bagian receiver dengan baik. Data asap juga berhasil dikirimkan dari transmitter menuju receiver. Hasil pengujian ditunjukkan oleh gambar 10.

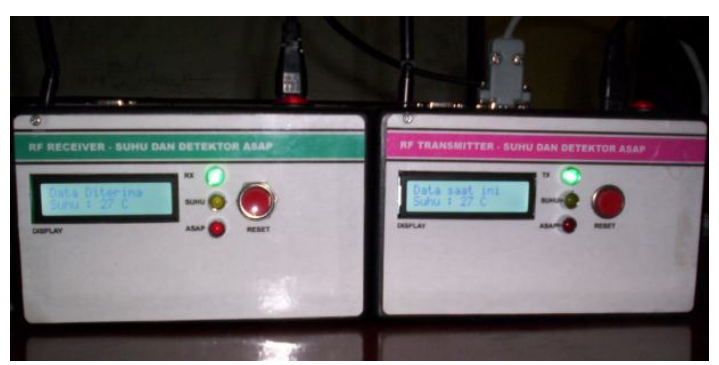

Gambar 10. Hasil pengujian pengiriman data dari transmitter menuju receiver

Pengiriman data dari bagian transmitter ke bagian receiver juga dilakukan pada jarak $200 \mathrm{~m}$ di udara terbuka. Hasil pengujian menunjukkan bahwa pada jarak tersebut, proses pengiriman data suhu dan asap dari bagian transmitter ke bagian receiver masih dapat dilakukan dengan baik.

\subsection{Hasil Pengujian Pembacaan Aplikasi}

\section{Antarmuka Komputer}

Pembacaan aplikasi antarmuka komputer dilakukan dengan menghubungkan bagian transmitter atau receiver ke serial komputer melalui kabel serial RS 232. Tampilan program aplikasi antarmuka dengan komputer ditunjukkan oleh gambar 11.

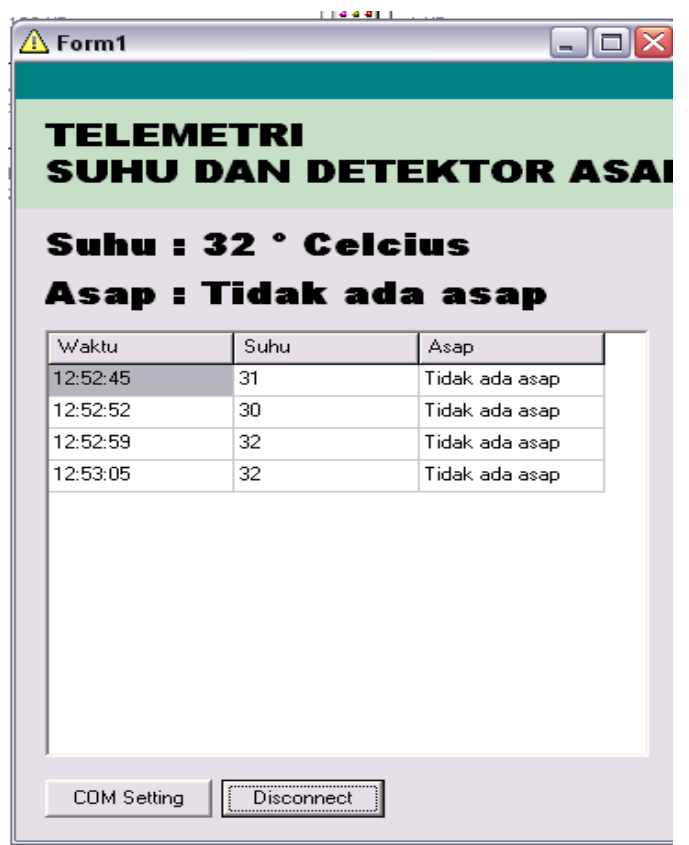

Gambar 11. Form tampilan program antarmuka komputer 


\section{Kesimpulan}

Berdasarkan hasil penelitian beserta pembahasan yang telah dijabarkan dapat diambil beberapa kesimpulan antara lain :

1. Telah berhasil dirancang suatu sistem telemetri untuk pengukuran suhu dan deteksi keberadaan asap.

2. Sistem telemetri yang dirancang dapat digunakan sebagai alat deteksi dini kebakaran lahan dikarenakan kemampuannya dalam mendeteksi kenaikan suhu lingkungan dan keberadaan asap.

\section{Daftar Pustaka}

[1]Budiharto, W., 2004, Interfacing Komputer dan Mikrokontroler, Elex Media Komputindo, Jakarta.

[2] Glasgow, H. B., Burkholder, J, M., Reed, R. E., Lewitus, A. J., Kleinman, J. E., 2004, Real Time Remote Monitoring of Water Quality: A Review of Current Applications, and Advantancements in Sensor, Telemetry, and Computing Technologies, Journal of Experimental Marine Biology and Ecology, 300, 409-448.

[3] Komarudin, M., Prosiding Seminar Nasional Sains dan Teknologi-II 2008 Universitas Lampung, 17-18 November 2008.

[4] National Semiconductor, 2000, LM35 Precision Centigrade Temperature Sensors, http://www.national.com/ds/LM/LM35.pdf , tanggal akses 1 Mei 2010.

[5] Ruchiat, Yayat., Penyebab dan Dampak Kebakaran Hutan dan Lahan, , Bahan Makalah Lokakarya Perencanaan Proyek Community development through rehabilitation of Imperata grasslands using trees: A model approach growing Vitex Pubescens for charcoal production in Kalimantan Indonesia Pontianak 23 Februari 2001

[6] Sukiswo, 2008, Perancangan Telemetri Suhu dengan Modulasi Digital FSK-FM, Transmisi, Vol. 10, No.2, Desember 2005, 1 - 8.

[7] Tsuchida, Y., Hama, N., Takahata, M., 2004, An Optical Telemetry System for Underwater recording of Electromyogram and Neural Activity, Journal of Neuroscience Methods, 137, 103-109.
[8] Ye Xuesong, PengWang, Jun Liu Zhang, S., Jiang, J., QingboWang, Chen, W., Zheng, X., 2008, A Portable Telemetry System for Brain Stimulation and Neural Activity Recording in Freely Behaving Small Animals, Journal of Neuroscience Methods, 174, 186-193. 